\title{
THE EFFECT OF HYALURONIC ACID TO PAIN INTENSITY RATED BY FACE PAIN SCALE-REVISED ON KNEE OSTEOARTHRITIS PATIENTS
}

\author{
Felicia Putri Hartono ${ }^{1)}$, Nunung Nugroho ${ }^{2)}$, Endang Isbandiati ${ }^{3)}$
}

\begin{abstract}
Introduction: Osteoarthritis (OA), is a chronic degenerative disease of joint associated with cartilage and joints. The most common symptoms of OA patients is joint pain that worsen in activity and relieved with rest. Hyaluronic acid (HA) injection is one of the treatment that used to relieved joint pain in OA patients.

Aim : The purpose of this study was to determine the effect of HA injection to pain intensity on knee OA degree 2 and 3 patients in PHC Hospital Surabaya.

Methods : Analytic research study design with retrospective cross-sectional study with purposive sampling technique. The respondents in this study were patients with knee OA degree 2 and 3 that had been failed with conservative therapeutics within 3 until 6 months and had been injected with HA in PHC Hospital in Surabaya. The number of respondents that have been collected that fulfill the inclusion and exclusion criteria were 46 respondents. Results : based on data analysis with Wilcoxon Signed Ranks Test there was an effect of HA injection in pain reduction on knee OA degree 2 and 3 patients $(\mathrm{p}=0,00001)$.

Conclusion : There is an effect of HA injection in pain reduction on knee OA degree 2 and 3 patients.
\end{abstract}

Keyword : Knee Osteoarthritis, Pain intensity, Face Pain Scale-Revised, Hyaluronic Acid Injection.

\footnotetext{
${ }^{1)}$ Student of Faculty of Medicine Widya Mandala Catholic University Surabaya, Kalisari Selatan 1 Surabaya Email : feliciahartono@gmail.com

${ }^{2)}$ Medical Rehabilitation Department Faculty of Medicine Widya Mandala Catholic University Surabaya, Kalisari Selatan 1 Surabaya

${ }^{3)}$ Clinical Pharmacology Department Faculty of Medicine Widya Mandala Catholic University Surabaya, Kalisari Selatan 1 Surabaya
} 


\section{INTRODUCTION}

Osteoarthritis

$(\mathrm{OA})$ is a degenerative disease of the joints that affects the cartilage and surrounding connective tissue. Changes that occur due to OA cause an imbalance from the overhaul and repair of joint tissue. The main symptoms of OA include joint pain, stiffness and limitation of motion that progressively and slowly results in disability. ${ }^{1}$ OA can occur at various ages, but is most often found in people over 65 years old. ${ }^{2}$ There are various risk factors including age, obesity, history of joint injury, joints that are often used, weak thigh muscles and genetics. One in two adults experience symptoms of knee osteoarthritis during their lifetime. Moreover, one in four adults experience waist symptoms at around 85 years of age. At last, one in twelve people aged 60 or over develop hand osteoarthritis.

According to the NCBI (National Center for Biotechnology Information), $\mathrm{OA}$ is one of the diseases that cause disabilities in the world. In the most recent recorded estimate, diseases related to the musculoskeletal system are ranked second, with back pain, neck pain, and knee OA being the three most common conditions. Based on the data from NHANES III (The Third National Health and Nutrition Examination Survey), among OA sufferers, about $80 \%$ of people have limited mobility and $25 \%$ are unable to do major activities, $11 \%$ of adults with knee OA need help from a private nurse, and $14 \%$ need help with daily activities. ${ }^{4} \mathrm{OA}$ is incurable and generally worsens along with age.

To improve the quality of life, many patients with a clinical diagnosis of $\mathrm{OA}$ are given a combination of nonpharmacological and pharmacological therapies. Options for nonpharmacological OA therapy include exercise and weight loss as well as the use of tools such as Shortwave Diathermy (SWD) and Transcutaneous Electrical Stimulation Nerve (TENS). There is also the provision of pharmacological therapies such as the administration of pain medications for NSAIDs and opioids.

One of the management of $\mathrm{OA}$ treatment that can be given in this case is by using hyaluronic acid injection. Hyaluronic acid (HA) injection is a viscosuplementation used to treat osteoarthritis. HA injection has many benefits for the treatment of OA. The known benefits are reducing pain due to $\mathrm{OA}$ and delaying the progression of $\mathrm{OA}^{6}$

HA injection as viscosuplementation has been used as one of the management of $\mathrm{OA}$ pain management in the United States since 1997. Some of the uses of HA have been described in research are as analgesic and 
anti-inflammatory. ${ }^{7}$ Regarding to the impact of patient satisfaction, it can be measured by assessing the degree of pain one of them by using the Face Pain Revised Scale (FPS-R). Based on the existing data, researchers conducted a study related to the effect of providing hyaluronic acid injection therapy on the degree of pain as assessed by FPS-R in knee osteoarthritis patients at PHC Hospital in Surabaya.

\section{METHODS}

The study design was an observational analytic study with a crosssectional retrospective study design. It used the data from medical records and conducted the interviews at the same time in OA patients, from January to June 2017, who have been injected with HA at PHC Hospital in Surabaya.

Samples from this study were OA patients with $2^{\circ}$ and $3^{\circ}$ on knee who had received conservative therapy for 3 to 6 months and had received HA injections at PHC Hospital in Surabaya. By this procedure, a total of 46 people were chosen. The inclusion criteria of the study were that the patient had received conservative therapy for 3 to 6 months but had failed, the patient had completed HA injection not distinguished by the number of injections and did not differentiate the HA molecular specific gravity, and the patient was $\mathrm{OA}$ diagnosed with $2^{\circ}$ and $3^{\circ}$ on knee through radiological and clinical. On the other hand, the exclusion criteria for the study were post-traumatic knee joint and surrounding tissue patients, postknee joint surgery patients, OA patients with $1^{\circ}$ and $4^{\circ}$ on knee, and patients who did not agree to participate in the study. The data is collected by purposive sampling which is one of the methods of non-probability sampling. This research was conducted at PHC Hospital in Surabaya which located at Jl. Prapat Kurung Selatan No.1, Tanjung Perak, Surabaya. The procedure used to determine the degree of OA on the knee is by looking at the patient's medical record data that is the patient's X-Ray of the knee. Furthermore, the procedure used to obtain the results of FPS-R patients before and after an intervention was given, it was also to conduct the interviews at the same time on the day of the study to determine changes in pain felt after getting HA injection in rehabilitation poly at $\mathrm{PHC}$ Hospital. Home visits can be made if the patient is unable to go to PHC Hospital with the patient's consent.

The measuring instrument used to determine joint pain is the FPS-R. The researcher asked the subjects to give a sign on one of the facial images that represented the pain felt. Each face picture has a rating ranging from 0 to 10 with a 
multiple of two but this score is not listed on the questionnaire sheet. Only researchers know the score of the face image listed.

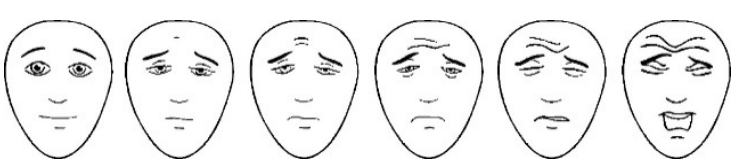

The collected data was analyzed by using SPSS and a Wilcoxon signed ranked test was performed to determine changes in the degree of pre-test and post-test pain.

\section{RESULT}

The distribution of Osteoarthritis respondents, who have injected, is based on the sex. The majority of respondents are female as many as 38 people $(82.6 \%)$ of the 46 total respondents

\begin{tabular}{lll}
\hline Sex & Amount & Percentage \\
\hline Male & 8 & $17,4 \%$ \\
\hline Female & 38 & $82,6 \%$ \\
\hline Total & 46 & $100 \%$ \\
\hline
\end{tabular}

Table 1 : The Sample Distribution Based on Sex

From Table 1, the distribution of Osteoarthritis respondents who have injected based on the degree of Osteoarthritis are the respondents aged 61 to 70 years $(50.0 \%)$ of 46 people in total respondents at most.

\begin{tabular}{lcc} 
Age & Amount & Percentage \\
\hline $41-50$ & 1 & $2,2 \%$ \\
\hline $251-60$ & 17 & $37,0 \%$ \\
\hline $261-70$ & 23 & $50,0 \%$ \\
\hline
\end{tabular}

$\begin{array}{lcc}\geq 71-80 & 3 & 6,5 \% \\ \geq 81-90 & 2 & 4,3 \% \\ \text { Total } & 46 & 100 \%\end{array}$

Table 2 : The Sample Distribution based on Age

From table 2, the distribution of Osteoarthritis respondents who have injected based on the degree of Osteoarthritis are the respondents aged 61 to 70 years $(50.0 \%)$ of 46 people total respondents at most.

It is known that the mean pain intensity of OA before HA injection is 7 which is included in moderate pain, the mean intensity of joint pain after HA injection is 3 which is included in mild pain. The hypothesis testing about the effect of injecting hyaluronic acid on pain intensity with Faces Pain Scale-Revised in patients with knee degrees 2 and 3 osteoarthritis at PHC Hospital in Surabaya is using the Wilcoxon Signed Ranks Test SPSS Statistics 21.0 with a significance level $\alpha=0.05$ indicating the value of $p=$ $0,000(\mathrm{p}<\alpha)$ which means that the hypothesis (H1) is accepted, so that there is an effect of giving hyaluronic acid injection to decrease the degree of pain in patients with knee osteoarthritis.

\section{Wilcoxon Signed Ranks Test}

Test Statistics $^{\text {a }}$

\begin{tabular}{|l|c|}
\hline & $\begin{array}{c}\text { Score of Pain After Injection - Score of } \\
\text { Pain Before Injection }\end{array}$ \\
\hline $\begin{array}{l}\text { Asymp. Sig. } \\
\text { (2-tailed) }\end{array}$ & $-5,705^{\mathrm{b}}$ \\
&, 00001 \\
\hline
\end{tabular}


a. Wilcoxon Signed Ranks Test

b. Based on positive ranks.

Table 3 : Wilcoxon Signed Rank Test on score of pain before and after injection

\section{DISCUSSION}

The results showed that the average intensity of respondent's pain before injection was 7 , it can still be categorized in moderate pain. Factors that can affect the intensity of OA pain are the degree of severity of OA according to radiology, gender, age, activity and others. There are factors that affect a person experiencing osteoarthritis as follows.

The first factor is because of the age. In the results of this study, the majority of respondents had ages ranging from $61-70$ years $(50.0 \%)$. This is in accordance with the journal YongPing Li, stated that in the world most people experiencing OA have an age above 65 years. ${ }^{8}$ In older people, the function of body cells begins to change. Cell and tissue aging occurs which makes an elderly person more susceptible to OA, especially OA which is caused due to an excess of mechanical stress. In the elderly due to aging that causes such an inadequate response. This can cause joint tissue damage in OA cases. This is also supported by the matrix aging theory of cartilages. In the elderly in addition to decreased homeostatic function also found thinning of the bone cartilage matrix.

The second factor is the sex of the respondent. In the results of this study, the majority of respondents is female $(82.6 \%)$. This is in accordance with the journal Knee Osteoarthritis in women. ${ }^{9}$ More women affected by osteoarthritis, it can be caused by various things including the influence of hormonal and anatomy of women who are different from men. The hormone that affects women is estrogen. This is also supported by research conducted by Niken and Lucia, stated that women, especially those from the age of 50 years, have a risk of 4.59 times experiencing OA compared to men.. ${ }^{10}$

After the respondents were given HA acid injection, the results showed the average pain intensity of the respondents reached number 3 . This was influenced by various factors including how active the patient was, patient compliance with the therapy given, patient psychological factors. In this study, all patients were given the same injection, HA injection.

As a matter of fact, the decrease in pain intensity can be felt differently depending on how active the patient is doing the activity. Patients who are quite active in their daily activities will feel more pain because their activities are better than before injection. In terms of reducing joint pain, each person can be 
different because even if the injection is done with the same number of psychological factors the patient can affect the results. Certain conditions such as depression or excessive anxiety can interfere with the results of HA injection therapy.

From the results of hypothesis testing about the effect of giving injection of hyaluronic acid to injection of hyaluronic acid on decreasing the degree of pain in patients with knee OA degrees 2 and 3 , it is obtained the $p$ value $=0.00001$ with a significant level $=0.05$. Because $p$ $=0.00001<\mathrm{a}=0.05$, the hypothesis $(\mathrm{H} 1)$ is accepted, which means that there is an influence of injection of hyaluronic acid to reduce the degree of pain in OA patients with knee degrees 2 and 3 at PHC Hospital in Surabaya. In this study, there were 2 types of injections given to patients, but this study did not discuss the types of injections available. Hyaluronic acid injection is one of the therapies given if the patient does not experience pain relief by giving non-pharmacological and pharmacological conservative therapy such as NSAID administration. HA has viscupplementation and viscoinduction properties. These two characteristics are taken as the hope that it can improve the quality of life of patients in this study is to reduce pain that can affect social activities in patients.
From the results of this study, it can be concluded that the administration of HA injection can reduce joint pain experienced by patients with knee OA. According to the journal Intra-Articular Injection for the Treatment of Osteoarthritis, ${ }^{11}$ injections of hyaluronic acid can provide two different functions according to how much force is applied. On the one hand, HA injection provides lubrication which facilitates the shifting of the joint to make movement and if there is stronger stress, HA can provide resistance so as to prevent injury to the joint.

\section{CONCLUSION}

This study can be concluded as follows:

1. The average pain intensity before being given injection therapy hyaluronic acid in knee osteoarthritis patients is included as many as seven in moderate pain.

2. Average pain intensity after injection of hyaluronic acid injection in knee osteoarthritis patients is included as many as three in mild pain.

Statistical test value $p=0.00001$ can be concluded that there is a significant effect on the administration of hyaluronic acid injection on the reduction in pain degree of knee osteoarthritis patients. 


\section{REFERENCES}

1. Litwic A, Edwards M, Dennison E, Cooper C. Epidemiology and Burden of Osteoarthritis [Internet]. British medical bulletin. U.S. National Library of Medicine; 2013 [disitasi 3 April 2017]. Diunduh dari:

https://www.ncbi.nlm.nih.gov/pmc/arti cles/PMC3690438/

2. Kumar V, Abbas A, Aster J. Robbins basic pathology. WB Saunders Elsevier.; 2012. 782-783

3. What is Osteoarthritis? [Internet]. www.arthritis.org. [cited 5 April 2017]. Diunduh dari: http://www.arthritis.org/aboutarthritis/types/osteoarthritis/what-isosteoarthritis.php

4. Neogi T. The Epidemiology and Impact of Pain in Osteoarthritis [Internet]. Osteoarthritis and cartilage / OARS, Osteoarthritis Research Society. U.S. National Library of Medicine; 2013 [Cited 27 Februari 2017]. Downloaded from: https://www.ncbi.nlm.nih.gov/pmc/arti cles/PMC3753584/\#S6title

5. Hamijoyo L. Pengapuran Sendi atau osteoartritis [Internet]. Perhimpunan Reumatologi Indonesia. [Cited in 28 February 2017]. Downloaded from: http://reumatologi.or.id/reujurtail?id=2 $\underline{9}$

6. Rezende MCA, Campos G. VISCOSUPPLEMENTATION. Revista Brasileira de Ortopedia (English Edition) [Internet]. 2012 [Cited in 6 June 2017];47(2):160-4. Downloaded from: https://www.ncbi.nlm.nih.gov/pmc/arti cles/PMC4799378/

7. Altman R, Manjoo A, Fierlinger A, Niazi F, Nicholls M. The mechanism of action for hyaluronic acid treatment in the osteoarthritic knee: a systematic review. BMC Musculoskeletal Disorders. 2015;16(1).

8. YongPing Li, XiaoChun Wei, JingMing Zhou, \& Lei Wei. The Age-
Related Changes in Cartilage and Osteoarthritis. 22 Juli 2013 [Cited in 5 November 2017]. Downloaded from: http://dx.doi.org/10.1155/2013/916530

9. Hame, S. L., \& Alexander, R. A. Knee osteoarthritis in women [Internet]. 8 Maret 2013 [Cited in 5 November 2017]. Downloaded from: https://www.ncbi.nlm.nih.gov/pmc/arti cles/PMC3702776/

10. Anggraini, N. E., \& Hendrati, L. Y. Hubungan Obesitas dan Faktor-Faktor Pada Individu dengan Kejadian Osteoarthritis Genu. Jurnal Berkala Epidemiologi. 2014; 2(1) : 93-104. Downloaded from: http://journal.unair.ac.id/downloadfull/ JBE8520-1e82f62ac4fullabstract.pdf

11. Iannitti T, Lodi D, Palmieri B. IntraArticular Injections for the Treatment of Osteoarthritis. Drugs in R\&D. 2011;11(1):13-27 